\title{
Cow characteristics and their association with udder health after different dry period lengths
}

\author{
R. J. van Hoeij, ${ }^{11}$ T. J. G. M. Lam,†‡ D. B. de Koning, ${ }^{*}$ W. Steeneveld,§ B. Kemp, ${ }^{*}$ and A. T. M. van Knegsel* \\ *Adaptation Physiology Group, Department of Animal Sciences, Wageningen University, PO Box 338, 6700 AH, Wageningen, the Netherlands \\ †Department Farm Animal Health, Utrecht University, PO Box 80151, 3508 TD, Utrecht, the Netherlands \\ fGD Animal Health, PO Box 9, 7400 AA, Deventer, the Netherlands \\ $\S$ Chair group Business Economics, Wageningen University, Hollandseweg 1, 6706 KN, Wageningen, the Netherlands
}

\begin{abstract}
Shortening or omitting the dry period (DP) in dairy cows is of interest because of potential beneficial effects on energy balance and metabolic health. Reported effects of a short or omitted dry period on udder health are ambiguous. This study aimed to evaluate the effect of no DP $(0 \mathrm{~d})$, a short DP $(30 \mathrm{~d})$, or a conventional DP $(60 \mathrm{~d})$ on the occurrence of intramammary infections (IMI) during the precalving period and on somatic cell counts (SCC), elevations of SCC (SCC $\geq 200,000$ cells/ $\mathrm{mL}$ ), and clinical mastitis in the subsequent lactation. The study also aimed to analyze which prepartum cow characteristics are associated with udder health after different DP lengths. Holstein-Friesian dairy cows $(\mathrm{n}=$ 167) were randomly assigned to a DP length $(0,30$, or $60 \mathrm{~d})$. Cows with a 0-d DP had a greater occurrence of chronic IMI and a lower occurrence of cured IMI during the precalving period than cows with a $30-\mathrm{d}$ or $60-\mathrm{d}$ DP. Postpartum average SCC for lactation was greater in cows with a 0 -d DP than in cows with a $30-d$ or $60-d$ DP. The number of cows with at least 1 elevation of SCC, the number of elevations of SCC per affected cow, the number of cows treated for clinical mastitis, and the number of cases of mastitis per affected cow did not differ among DP lengths. Cow characteristics related to postpartum average SCC for lactation were DP length, parity, and the following interactions: DP length with prepartum elevation of SCC, DP length with fat- and protein-corrected milk (FPCM) reduction between 150 and $67 \mathrm{~d}$ prepartum, DP length with parity and with average SCC for lactation, and last FPCM before the conventional drying-off day with average SCC for lactation. Cows with prepartum parity 1 had a lower occurrence of at least 1 elevation of SCC in subsequent lactation compared with cows with parity $>2$. Last SCC before the conventional drying-off
\end{abstract}

Received February 2, 2016.

Accepted June 6, 2016.

${ }^{1}$ Corresponding author: renny.vanhoeij@wur.nl day was positively associated with occurrence of clinical mastitis in the subsequent lactation. In this study, DP length was not a risk factor for either elevation of SCC or occurrence of clinical mastitis in the subsequent lactation. The identified cow characteristics could be used in a decision support model to optimize DP length for individual cows.

Key words: continuous milking, decision making, somatic cell count, clinical mastitis

\section{INTRODUCTION}

Shortening or omitting the dry period (DP) may potentially improve energy balance and reduce the risk of ketosis at the start of the subsequent lactation (van Knegsel et al., 2013). The histology of udder tissue at different prepartum time points indicates that a DP of at least $35 \mathrm{~d}$ is needed for proliferation and cell turnover to increase the proportion of epithelial cells in the udder for milk synthesis (Capuco et al., 1997). Milk production does not differ between a 30-d DP or a 60-d DP (Gulay et al., 2003); however, a 0-d DP allows the udder little or no time to regenerate secretory cells compared with a 60-d DP, which could explain the lower milk yield after a 0-d DP (Capuco et al., 1997). Lower milk yield requires less energy, which explains the better energy balance and improved metabolic status in early lactation for cows with a $30-\mathrm{d}$ or 0 -d DP (Grummer and Rastani, 2004; Watters et al., 2008; Chen et al., 2015).

The effect of DP length on udder health is unclear. Studies showed that following a 30-d or 0-d DP, SCC in the subsequent lactation tended to decrease ( $\mathrm{Gu}-$ lay et al., 2003; Pinedo et al., 2011), was not affected (Rastani et al., 2005; Church et al., 2008; Watters et al., 2008; Bernier-Dodier et al., 2010), or tended to increase compared with a 60-d DP (Kuhn et al., 2006; Pezeshki et al., 2007; Steeneveld et al., 2013). A 30-d DP tended to reduce the number of new IMI postpartum (Pezeshki et al., 2007; Pinedo et al., 2011), but other studies indicated no effect of DP length on clini- 
cal mastitis in the subsequent lactation compared with a 60-d DP (Church et al., 2008; Watters et al., 2008; Shoshani et al., 2014). Overall, results are ambiguous, and no definite conclusions can be drawn because too little research has been done on the effect of DP length on udder health (Collier et al., 2012).

The effect of DP length on udder health in the subsequent lactation may be related to other cow characteristics such as parity, calving month, occurrence of clinical mastitis in the previous lactation, SCC before drying off, and milk yield during the days before drying off (Green et al., 2007; Pantoja et al., 2009b). We previously showed that part of the effect of DP length on postpartum milk yield can be explained by differences in parity, milk yield at drying off, and persistency in the previous lactation (Steeneveld et al., 2014). It can be hypothesized that the effect of DP length on udder health in the subsequent lactation is also explained by prepartum cow characteristics such as parity, milk production, and SCC. These cow characteristics could be used in a decision support model to optimize DP length for individual cows.

The aims of this study were to evaluate the effect of a $0-\mathrm{d}, 30-\mathrm{d}$, and $60-\mathrm{d}$ DP on IMI during the precalving period on SCC, elevations of SCC, and clinical mastitis in the subsequent lactation. Another aim was to analyze which prepartum cow characteristics are associated with these udder health variables after different DP lengths.

\section{MATERIALS AND METHODS}

\section{Animals, Experimental Design, and Housing}

The experimental protocol was approved by the Institutional Animal Care and Use Committee of Wageningen University as earlier described (van Knegsel et al., 2014). The experiment was originally designed to study the effects of DP length and dietary energy source on milk characteristics, energy balance, and plasma metabolites. The experiment was conducted at the Dairy Campus research herd (Lelystad, the Netherlands), with 167 Holstein-Friesian cows (60 primiparous and 107 multiparous) between May 10, 2010, and September 30, 2012. The research herd comprised 400 lactating Holstein cows. Cows for this experiment were selected based on (1) being bred with a Holstein sire, (2) an expected calving interval $<490 \mathrm{~d}$, (3) daily milk yield $>16 \mathrm{~kg}$ at $90 \mathrm{~d}$ before the expected calving date, and (4) no clinical mastitis or high SCC ( $>250,000$ cells/ $\mathrm{mL})$ at 2 test-days before the conventional drying-off day ( $67 \mathrm{~d}$ before the expected calving date). Cows were blocked for prepartum parity $(1,2$, or $>2)$, expected calving date, milk production, and BCS. Each block consisted of 6 cows. Within blocks, cows were randomly assigned to a DP length (0, 30, or $60 \mathrm{~d})$ and an early lactation ration (glucogenic or lipogenic) resulting in a $3 \times 2$ factorial design. Ration was included in the experimental setup because its effect on negative energy balance was evaluated in an earlier study (van Knegsel et al., 2014). Ration composition and feeding strategies were described earlier (van Knegsel et al., 2014). Briefly, during the precalving period, lactating cows were fed a lactation ration supporting $25 \mathrm{~kg}$ of milk, and dry cows were fed a dry cow ration. From 10 $\mathrm{d}$ before the expected calving date and onwards, cows of all treatments were fed $1 \mathrm{~kg} / \mathrm{d}$ of concentrate, which increased stepwise at $0.5 \mathrm{~kg} / \mathrm{d}$ postpartum until reaching $8.5 \mathrm{~kg} / \mathrm{d}$. The basal dry cow and lactation ration consisted of grass silage, corn silage, wheat straw, rapeseed meal or soybean meal, and vitamins and minerals. Rations were formulated to be equal in net energy for lactation, rumen undegradable protein, and rumen degradable protein, as described earlier by van Knegsel et al. (2014). Preliminary analyses showed no effect of ration on average SCC for lactation or elevations of SCC or clinical mastitis. Ration was therefore excluded from further analyses in this study.

Cows were housed in a freestall barn with slatted floors and cubicles. Cows were milked twice daily. The drying-off protocol for cows with a $30-\mathrm{d}$ or $60-\mathrm{d}$ DP consisted of a transition to the dry cow ration at $\mathrm{d} 7$ before the actual drying-off day and transition to milking once daily at $\mathrm{d} 4$ before the actual drying-off day. At drying off, cows with a 30-d or 60-d DP received intramammary treatment with a dry cow antibiotic (Supermastidol, Virbac Animal Health, Barneveld, the Netherlands).

Clinical mastitis cases were diagnosed and recorded by the milkers at the Dairy Campus research herd during the morning or evening milking. A case of clinical mastitis was defined as a treated case of visibly abnormal milk, changes in the udder due to inflammation, or both. All cows with clinical mastitis were treated with antibiotics according to the herd-specific treatment plan based on severity of disease.

\section{Milk Collection and Analysis}

Milk yield, milk fat and protein, and SCC for the lactation before the DP of study were available monthly for each cow and were obtained from the Dutch national milk recording system (CRV, Arnhem, the Netherlands). After calving, milk yield, milk fat and protein, and SCC were available weekly until the end of lactation (wk 44 postpartum) for each cow. Milk samples for analysis of fat, protein, and SCC (Qlip, Zutphen, the Netherlands) were collected 4 times weekly (Tuesday 
Table 1. Number of available observations per prepartum variable for cows with a dry period (DP) length of 0,30 , or $60 \mathrm{~d}$

\begin{tabular}{lcccc}
\hline & \multicolumn{3}{c}{ DP length (d) } & \\
\cline { 2 - 3 } Variable & 0 & 30 & 60 & \multirow{2}{*}{ Total } \\
\hline No. of cows & 56 & 55 & 56 & 167 \\
Precalving variable & & & & \\
$\quad$ Complete lactation precalving & 54 & 50 & 52 & 156 \\
$\quad$ Total lactation yield & 56 & 55 & 55 & 166 \\
SCC and milk yield between 150 and 67 d prepartum & 55 & 55 & 56 & 166 \\
$\quad$ Last SCC and last FPCM before DP & 54 & 53 & 54 & 161 \\
Postcalving variable & & & & 111 \\
$\quad$ Complete lactation (44 wk) & 35 & 36 & 40 & 1 \\
\hline
\end{tabular}

${ }^{1} \mathrm{FPCM}=$ fat- and protein-corrected milk.

afternoon, Wednesday morning, Wednesday afternoon, and Thursday morning) and pooled per week.

\section{Statistical Analyses}

Data Handling. Statistical analyses were performed using SAS version 9.3 (SAS Institute Inc., 2011). The natural logarithm of SCC (lnSCC) was used for analyses to approximate normality. Some prepartum variables were not available for all cows due to missing milk records (Table 1). The final data set consisted of 1,983 prepartum test-days (median -202 ; range -496 to -1 DIM) and 7,348 postpartum test-days (median 147; range 1-307 d in milk) of 167 cows between May 7, 2009, and September 30, 2012.

Milk Yield and Udder Health Before and After Different DP Lengths in Cows of Different Parities. To compare prepartum variables for different DP lengths and to analyze the effect of DP length on postpartum udder health, a mixed linear model (PROC MIXED) was used. The dependent variables in the statistical analysis were total lactation yield (305-d milk production in $\mathrm{kg}$ ) and average $\mathrm{SCC}$ in the complete previous lactation. The dependent variables between 150 and $67 \mathrm{~d}$ prepartum were fat- and protein-corrected milk (FPCM) production $(\mathrm{kg} / \mathrm{d})$, FPCM reduction $(\mathrm{kg})$, and SCC. The dependent variables on the last test-day before the conventional drying-off day $(67 \mathrm{~d}$ before the expected calving date) were last FPCM and last SCC. The independent variables were DP length $(0,30$, or $60 \mathrm{~d})$, prepartum parity $(1,2$, or $>2)$, and calving season (meteorological winter, spring, summer, or autumn). The following mixed linear model (PROC MIXED) was used:

$$
\begin{aligned}
y_{i j k}= & \mu+\mathrm{DP}_{i}+\text { Parity }_{j}+\left(\mathrm{DP} \times \text { Parity }_{i j}\right. \\
& + \text { Season }_{k}+\varepsilon_{i j k},
\end{aligned}
$$

where $y_{i j k}$ indicates the ijkth observation of a continuous prepartum variable. The mean is represented by $\mu$. $\mathrm{DP}_{i}$ indicates the DP length $(i=0,30$, or $60 \mathrm{~d})$, Parity $_{j}$ indicates the parity of the cow prepartum $(j=$ parity $1,2$, or $>2),(\mathrm{DP} \times \text { Parity })_{i j}$ indicates the interaction between DP and parity, Season $_{k}$ indicates the random effect of calving season $(k=$ meteorological winter, spring, summer, or autumn), and the random residual term from a normal distribution is indicated by $\varepsilon_{i j k}$.

For analyses of postpartum SCC between 2 and 44 wk of lactation, Model [1] was used with a repeated measurement effect consisting of postpartum lactation weeks with cows as the subject. A first-order heterogeneous autoregressive covariance matrix $[\mathrm{ARh}(1)]$ was the best fit according to Akaike's corrected information criterion and was used to account for within-cow variation. The dependent variable in the statistical analysis was postpartum weekly SCC between 2 and 44 wk of lactation. The independent variables in model [2] remained the same as in model [1], except for the addition of the repeated measurement effect. The following mixed linear model (PROC MIXED) was used:

$$
\begin{aligned}
y_{i j k l}= & \mu+\mathrm{DP}_{i}+\text { Parity }_{j}+\left(\mathrm{DP} \times \text { Parity }_{i j}+\mathrm{Week}_{k}\right. \\
& + \text { Season }_{l}+\varepsilon_{i j k l},
\end{aligned}
$$

where $y_{i j k l}$ indicates the $i j k l$ th observation of a postpartum SCC.

For binary variables, Model [1] was used with a binary distribution for the dependent variables in this model and the default logit link function to model the mixed linear regression analysis using PROC GLIMMIX. Dependent binary variables in the complete previous lactation were at least 1 elevation of SCC and at least 1 case of clinical mastitis for each cow. Dependent postpartum binary variables were at least 1 elevation of SCC between 3 and 44 wk postpartum and at least 
1 case of clinical mastitis between 1 and 44 wk postpartum for each cow. An elevation of SCC was defined as SCC $\geq 200,000$ cells/mL after 2 previous weeks with SCC $<200,000$ cells $/ \mathrm{mL}$ (Schukken et al., 2003).

Differences in number of elevations of SCC per cow prepartum, cases of clinical mastitis per cow prepartum, elevations of SCC per cow postpartum, and cases of clinical mastitis per cow postpartum were analyzed using Model [1] with a Poisson distribution for the dependent variables and the default log link function in a mixed linear regression analysis (PROC GLIMMIX).

Occurrence of IMI During Different DP Lengths. To evaluate whether new IMI had occurred during the precalving period, the last SCC before $67 \mathrm{~d}$ prepartum (median $-83 \mathrm{~d}$; range -100 to $-68 \mathrm{~d}$ prepartum) was compared with the first SCC postpartum, excluding the first week of lactation (median $13 \mathrm{~d}$; range 10-23 d postpartum). Cows were considered infected if SCC was $\geq 200,000$ cells $/ \mathrm{mL}$. Somatic cell counts before and after the DP were compared with cows categorized as having a chronic IMI (SCC $\geq 200,000$ cells $/ \mathrm{mL}$ before and after the DP), not being infected (SCC $<200,000$ cells $/ \mathrm{mL}$ before and after the DP), having a new IMI (SCC $<200,000$ cells $/ \mathrm{mL}$ before and SCC $\geq 200,000$ cells/mL after the DP), or being cured (SCC $\geq 200,000$ cells $/ \mathrm{mL}$ before and SCC $<200,000$ cells $/ \mathrm{mL}$ after the DP). The difference in incidence risks of IMI among DP lengths was analyzed using the following logistic regression model in PROC LOGISTIC (model [3]):

$$
\operatorname{Logit} P\left(y_{i j}=1\right)=\alpha+\mathrm{DP}_{i}+\varepsilon_{j}
$$

in which the model estimates the probability $(P)$ that the $i j$ th observation of postpartum IMI $(y)$ is 1 . Within observations of high SCC prepartum, chronic IMI $=1$ and cured $\mathrm{IMI}=0$. Within observations of low $\mathrm{SCC}$ prepartum, new IMI $=1$ and no IMI $=0$. Logit is the link function used to model the regression analysis, $\alpha$ is the estimate of the baseline odds of occurrence of IMI, $\mathrm{DP}_{i}$ indicates the DP length $(i=0,30$, or $60 \mathrm{~d})$, and the random residual term from a binary distribution is represented by $\varepsilon_{j}$.

Association of Prepartum Milk Yield and Udder Health with Postpartum Udder Health. The association of the prepartum variables and DP length with postpartum udder health was analyzed. To evaluate which cow characteristics are associated with postpartum SCC, a mixed linear model (PROC MIXED) was used. The dependent variable in this statistical analysis was postpartum SCC. For postpartum SCC, the univariable and multivariable models were assessed with the addition of a repeated measurement effect consisting of postpartum lactation weeks with cow as the subject. A first-order heterogeneous autoregressive covariance matrix $[\mathrm{ARh}(1)]$ was the best fit according to Akaike's corrected information criterion and was used to account for within-cow variation.

To evaluate which cow characteristics are associated with the binary variables at least 1 elevation of SCC between 3 and 44 wk postpartum, and at least 1 case of clinical mastitis between 1 and 44 wk postpartum for each cow, a mixed linear regression model (PROC GLIMMIX) was used. The univariable and multivariable models were assessed using a binary distribution for the dependent variables in this model, with a logit link function to model the mixed linear regression analysis. The dependent variables in these 2 statistical analyses were postpartum elevations of SCC and postpartum clinical mastitis.

The independent variables in all 3 statistical analyses were total lactation yield (305-d milk production in $\mathrm{kg}$ ) and average SCC for lactation in the complete previous lactation. The dependent variables between 150 and 67 d prepartum were FPCM production (kg/d), FPCM reduction $(\mathrm{kg})$, and SCC. The dependent variables on the last test-day before the conventional drying-off day (67 $\mathrm{d}$ before the expected calving date) were last FPCM and last SCC. The fixed independent variables were DP length $(0,30$, or $60 \mathrm{~d})$, prepartum parity $(1,2$, or $>2$ ), and calving season (meteorological winter, spring, summer, or autumn).

First, dependent variables were analyzed with each of the independent variables in a univariable model. Independent variables with $P \leq 0.20$ were included in a multivariable model for each dependent variable. In the multivariable models, variables were analyzed using a backward elimination procedure with a stay-in $P$-value of $\leq 0.05$ in the Wald test, except for the fixed effects described in Models [1] and [2] that remained in the models at all times. After backward elimination, all possible 2-way interactions and 3 -way interactions were tested and were maintained in the model when $P \leq$ 0.05 in the Wald test and when the interaction lowered Akaike's information criterion of the model $(P \leq 0.05)$.

\section{RESULTS}

\section{Udder Health and Milk Production Before the Conventional Drying-Off Day}

Cows with a $0-\mathrm{d}$ DP were on average 385 DIM $( \pm 5.5$ DIM) at the day before calving. Cows with a $30-d$ DP were on average 367 DIM $( \pm 6.4$ DIM) at drying off, and cows with a 60-d DP were on average 335 DIM $( \pm 7.3$ DIM) at drying off. Last milk yield before drying off was greater in cows with a $60-\mathrm{d}$ DP $(9.4 \pm 0.5$ $\mathrm{kg})$ than in cows with a 30 -d DP $(7.4 \pm 0.5 \mathrm{~kg})$. Milk 
production in cows with a 0 -d DP was $6.8 \mathrm{~kg}( \pm 0.5 \mathrm{~kg})$ at the day before calving.

Prepartum average SCC for lactation, occurrence of at least 1 elevation of SCC, and clinical mastitis did not differ among DP lengths (Table 2). Parity effects, however, were present. Cows with parity 1 had a lower FPCM reduction between 150 and $67 \mathrm{~d}$ prepartum $(P$ $<0.01)$ and tended to have a lower occurrence of clinical mastitis $(P=0.07)$ and a lower number of cases of clinical mastitis per treated cow $(P=0.06)$ compared with cows with parity $>2$. Cows with parity 1 had a lower $(P<0.01)$ total lactation yield, lower SCC at last test-day before the conventional drying-off day, and lower number of elevations of SCC per affected cow, compared with cows with parity 2 or parity $>2$. Lower parity was associated with lower average SCC for lactation, lower SCC between 150 and $67 \mathrm{~d}$ prepartum, and lower number of cows showing at least 1 elevation of SCC $(P<0.01)$. Regardless of DP length or parity, cows with an IMI (SCC $\geq 200,000$ cells $/ \mathrm{mL}$ ) on the last test-day before the conventional drying-off day had a greater FPCM reduction between 150 and $67 \mathrm{~d}$ prepartum $(6.2 \pm 0.7 \mathrm{~kg})$, compared with cows that had no IMI on the last test-day $(4.4 \pm 0.4 \mathrm{~kg})(P$ $=0.03)$.

\section{Udder Health After Different DP Lengths}

The actual DP length was $2 \pm 1 \mathrm{~d}$ for cows with a 0 - $\mathrm{d}$ DP, $30 \pm 1 \mathrm{~d}$ for cows with a $30-\mathrm{d}$ DP, and $61 \pm 1 \mathrm{~d}$ for cows with a 60 -d DP (mean \pm SEM). Postpartum SCC differed for parity and among DP lengths (Table 2). The interaction of DP length with parity resulted in the greatest postpartum SCC in cows with parity $>2$ and a 0-d DP (lnSCC $5.33 \pm 0.08)$ and the lowest postpartum SCC in cows with parity 1 and a $30-\mathrm{d}$ or $60-\mathrm{d}$ DP (lnSCC $4.33 \pm 0.08$ and $4.38 \pm 0.08$, respectively) $(P$ $=0.02)$. Lower parity $(P<0.01)$ was associated with a smaller number of cows showing at least 1 elevation of SCC or clinical mastitis in the subsequent lactation.

\section{Occurrence of IMI During Different DP Lengths}

The prevalence of $\mathrm{SCC} \geq 200,000$ cells $/ \mathrm{mL}$ on the last test-day before the conventional drying-off day was not different $(P=0.75)$ among DP lengths (Table 3$)$. At the first test-day after calving, cows with a 0-d DP had a greater prevalence of SCC $\geq 200,000$ cells $/ \mathrm{mL}$ than cows with a $60-\mathrm{d}$ DP $(P=0.05)$. Compared with cows with a 0 -d DP, the proportion of cows with a chronically high $\mathrm{SCC} \geq 200,000$ cells/mL after the DP was lower and the cure rate was greater in cows with a $30-\mathrm{d}$ or $60-\mathrm{d}$ DP $(P=0.04)$. The proportion of cows with a newly high SCC $\geq 200,000$ cells/mL or no infec- tion after the DP did not differ among DP lengths $(P$ $=0.58)$.

\section{Predictors for SCC, Elevation of SCC, and Clinical Mastitis After Different DP Lengths}

$\boldsymbol{S C C}$. Based on the univariable model, 10 prepartum variables were found to be related $(P<0.20)$ to postpartum average SCC for lactation: DP length, parity, clinical mastitis, at least 1 elevation of SCC, total lactation yield, average SCC for lactation, FPCM reduction and SCC between 150 and $67 \mathrm{~d}$ prepartum, and last FPCM and last SCC before the conventional drying-off day. After backward elimination, 6 prepartum variables remained in the multivariable model: DP length $(P=0.52)$, parity $(P<0.01)$, at least 1 elevation of SCC $(P=0.02)$, FPCM reduction $(P<0.01)$, last FPCM before the conventional drying-off day $(P$ $<0.01)$, and average SCC in the previous lactation $(P$ $=0.05)$ (Table 4$)$. Significant 2 -way interactions were present of DP length with parity $(P<0.01)$, DP length with elevations of SCC $(P<0.01)$, DP length with FPCM reduction $(P=0.04)$, and last FPCM with average SCC for lactation $(P<0.01)$. A significant 3 -way interaction was present of DP length with parity and average SCC for lactation $(P<0.01)$.

Elevation of $\boldsymbol{S C C}$. Based on the univariable models, 8 prepartum variables were related $(P<0.20)$ to at least 1 elevation of SCC postpartum: parity, occurrence of clinical mastitis, total lactation yield, average SCC for lactation, FPCM reduction and SCC between 150 and $67 \mathrm{~d}$ prepartum, and last FPCM and last SCC before the conventional drying-off day. In the multivariable model only parity $(P=0.03)$ remained, independent of DP length (Table 5). Cows with parity 1 showed at least 1 elevation of SCC in the subsequent lactation less often.

Clinical Mastitis. Based on the univariable models, 7 prepartum variables were related $(P<0.20)$ to at least 1 case of clinical mastitis postpartum: parity, clinical mastitis prepartum, total lactation yield, average SCC for lactation, SCC between 150 and $67 \mathrm{~d}$ prepartum, and last SCC before the conventional drying-off day. In the multivariable model only last SCC before the conventional drying-off day $(P<0.01)$ remained, independent of DP length (Table 5). Cows with a greater last SCC before the conventional drying-off day had 2 times greater odds of having at least 1 case of clinical mastitis in the subsequent lactation.

\section{DISCUSSION}

Postpartum SCC was greater in cows with a 0 -d DP than in cows with a $30-d$ or $60-d$ DP. The greater 
Table 2. Prepartum milk production and udder health variables and postpartum udder health variables for cows with a 0-, 30-, or 60-d dry period based on a mixed model with dry period length, parity, and their 2-way interaction as fixed variables (LSM \pm SEM)

\begin{tabular}{|c|c|c|c|c|c|c|c|c|c|c|c|}
\hline \multirow[b]{2}{*}{ Variable } & \multicolumn{3}{|c|}{ Dry period length $(\mathrm{d})$} & \multirow[b]{2}{*}{ SEM } & \multicolumn{3}{|c|}{ Parity } & \multirow[b]{2}{*}{ SEM } & \multicolumn{3}{|c|}{$P$-value ${ }^{1}$} \\
\hline & 0 & 30 & 60 & & 1 & 2 & $>2$ & & DP & $\mathrm{P}$ & $\mathrm{DP} \times \mathrm{P}$ \\
\hline Cows (no.) & 56 & 55 & 56 & & 60 & 53 & 54 & & & & \\
\hline \multicolumn{12}{|l|}{ Prepartum variables ${ }^{2}$} \\
\hline Total lactation $(305 \mathrm{~d})$ yield ( $\mathrm{kg}$ of milk) & 9,976 & 9,993 & 10,028 & 156 & $8,989^{\mathrm{a}}$ & $10,310^{\mathrm{b}}$ & $10,698^{\mathrm{b}}$ & 156 & 0.97 & $<0.01$ & 0.21 \\
\hline FPCM reduction between 150 and $67 \mathrm{~d}$ prepartum $(\mathrm{kg})$ & -6 & -5 & -4 & 0.71 & $-4^{\mathrm{a}}$ & $-5^{\mathrm{ab}}$ & $-6^{\mathrm{b}}$ & 0.71 & 0.16 & $<0.01$ & 0.83 \\
\hline FPCM between 150 and $67 \mathrm{~d}$ prepartum (kg/d) & 27 & 27 & 27 & 0.72 & 27 & 27 & 27 & 0.72 & 0.80 & 0.98 & 0.39 \\
\hline Last FPCM $67 \mathrm{~d}$ prepartum $(\mathrm{kg} / \mathrm{d})$ & 24 & 25 & 25 & 0.75 & 25 & 25 & 24 & 0.74 & 0.70 & 0.41 & 0.44 \\
\hline Average SCC for lactation ${ }^{3}$ & 4.25 & 4.35 & 4.13 & 0.09 & $3.96^{\mathrm{a}}$ & $4.27^{\mathrm{b}}$ & $4.60^{\mathrm{c}}$ & 0.09 & 0.12 & $<0.01$ & 0.83 \\
\hline SCC between 150 and $67 \mathrm{~d}$ prepartum ${ }^{3}$ & 4.56 & 4.52 & 4.46 & 0.09 & $3.99^{\mathrm{a}}$ & $4.56^{\mathrm{b}}$ & $5.00^{\mathrm{c}}$ & 0.09 & 0.72 & $<0.01$ & 0.38 \\
\hline Last SCC before $67 \mathrm{~d}_{\text {prepartum }}^{3}$ & 4.73 & 4.70 & 4.52 & 0.11 & $4.08^{\mathrm{a}}$ & $4.82^{\mathrm{b}}$ & $5.06^{\mathrm{b}}$ & 0.11 & 0.33 & $<0.01$ & 0.25 \\
\hline Elevations of SCC (\% cows $)^{4}$ & 41 & 42 & 34 & & $20^{\mathrm{a}}$ & $43^{\mathrm{b}}$ & $56^{\mathrm{c}}$ & & 0.57 & $<0.01$ & 0.65 \\
\hline Elevations of SCC (no. of cases/affected cow $)^{5}$ & 1.26 & 1.30 & 1.26 & & $1.08^{\mathrm{a}}$ & $1.30^{\mathrm{b}}$ & $1.33^{\mathrm{b}}$ & & 0.37 & $<0.01$ & 0.41 \\
\hline Clinical mastitis (\% cows) & 25 & 20 & 15 & & $10^{\mathrm{a}}$ & $23^{\mathrm{ab}}$ & $28^{\mathrm{b}}$ & & 0.37 & 0.07 & $\mathrm{NM}^{6}$ \\
\hline Clinical mastitis (no. of cases/affected cow) ${ }^{5}$ & 1.29 & 1.18 & 1.00 & & $1.00^{\mathrm{a}}$ & $1.17^{\mathrm{ab}}$ & $1.27^{\mathrm{b}}$ & & 0.18 & 0.03 & NM \\
\hline \multicolumn{12}{|l|}{ Postpartum variables (1-44 wk in lactation) } \\
\hline Average SCC for lactation ${ }^{3,5}$ & $5.01^{\mathrm{a}}$ & $4.68^{\mathrm{b}}$ & $4.52^{\mathrm{c}}$ & 0.06 & $4.49^{\mathrm{a}}$ & $4.71^{\mathrm{b}}$ & $5.01^{\mathrm{c}}$ & 0.06 & $<0.01$ & $<0.01$ & 0.02 \\
\hline Elevations of SCC (\% cows $)^{4}$ & 79 & 78 & 79 & & $67^{\mathrm{a}}$ & $83^{\mathrm{b}}$ & $87^{\mathrm{c}}$ & & 0.99 & 0.03 & 0.94 \\
\hline Elevations of SCC (no. of cases/affected cow) ${ }^{5}$ & 2.30 & 2.29 & 1.77 & & $1.83^{\mathrm{a}}$ & $2.20^{\mathrm{b}}$ & $2.28^{\mathrm{b}}$ & & 0.22 & $<0.01$ & 0.62 \\
\hline Clinical mastitis (\% cows) & 27 & 25 & 25 & & $13^{\mathrm{a}}$ & $30^{\mathrm{b}}$ & $35^{\mathrm{c}}$ & & 0.95 & 0.03 & 0.98 \\
\hline Clinical mastitis (no. of cases/affected cow) ${ }^{5}$ & 1.44 & 1.36 & 1.21 & & $1.00^{\mathrm{a}}$ & $1.19^{\mathrm{b}}$ & $1.63^{\mathrm{b}}$ & & 0.80 & $<0.01$ & 0.99 \\
\hline
\end{tabular}

${ }^{\mathrm{a}-\mathrm{c}}$ Values within dry period length or parity, within a row with different superscripts differ $(P<0.05)$.

${ }^{1} \mathrm{DP}=$ dry period length; $\mathrm{P}=$ parity; $\mathrm{DP} \times \mathrm{P}=$ interaction of dry period length with parity.

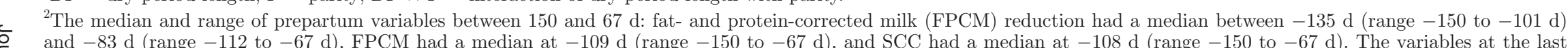
and $-83 \mathrm{~d}$ (range -112 to $-67 \mathrm{~d}$ ), FPCM had a median at $-109 \mathrm{~d}$ (range -150 to $-67 \mathrm{~d}$ ), and SCC had a median at $-108 \mathrm{~d}$ (range -150 to $-67 \mathrm{~d}$ ). The variables at the las
test-day before the conventional drying-off day ( $67 \mathrm{~d}$ before the expected calving date): last FPCM had a median at $-84 \mathrm{~d}$ (range -121 to $-67 \mathrm{~d}$ ), and last SCC had a median at $-83 \mathrm{~d}$ (range -100 to $-68 \mathrm{~d}$ )

을 ${ }^{3} \mathrm{SCC}$ is shown as the natural logarithm of SCC $(\operatorname{lnSCC})$.

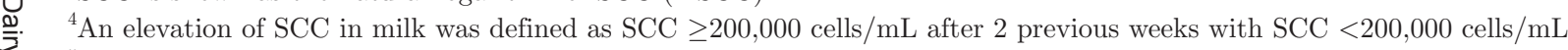

i ${ }^{5}$ For FPCM, SCC, and cases per affected cow, week was included in the model $(P<0.01)$.

ก). ${ }^{6}$ Not in model. 
Table 3. Proportion (and number) of cows with a high SCC $(\geq 200,000$ cells $/ \mathrm{mL})$ at the last test-day before the conventional drying-off day $(67 \mathrm{~d}$ prepartum) and at the first test-day $(10 \mathrm{~d}$ postpartum) after a 0 -, $30-$, or 60-d dry period (DP)

\begin{tabular}{|c|c|c|c|c|}
\hline \multirow[b]{2}{*}{ Variable } & \multicolumn{3}{|c|}{ DP length (d) } & \multirow[b]{2}{*}{$P$-value } \\
\hline & 0 & 30 & 60 & \\
\hline Total no. of cows & 54 & 53 & 54 & \\
\hline SCC $<200,000$ prepartum & $81(44)$ & $75(40)$ & $78(42)$ & \\
\hline SCC $\geq 200,000$ prepartum & $19(10)$ & $25(13)$ & $22(12)$ & 0.75 \\
\hline SCC $<200,000$ postpartum & $74(40)$ & $87(46)$ & $89(48)$ & \\
\hline $\mathrm{SCC} \geq 200,000$ postpartum & $26^{\mathrm{a}}(14)$ & $13^{\mathrm{ab}}(7)$ & $11^{\mathrm{b}}(6)$ & 0.09 \\
\hline \multicolumn{5}{|l|}{ High $\overline{\mathrm{SCC}}$ prepartum } \\
\hline Chronic IMI $^{1}$ & $50^{\mathrm{a}}(5)$ & $8^{\mathrm{b}}(1)$ & $8^{\mathrm{b}}(1)$ & 0.04 \\
\hline Cured $\mathrm{IMI}^{2}$ & $50^{\mathrm{a}}(5)$ & $92^{\mathrm{b}}(12)$ & $92^{\mathrm{b}}(11)$ & 0.04 \\
\hline \multicolumn{5}{|l|}{ Low SCC prepartum } \\
\hline New $\mathrm{IMI}^{3}$ & $20(9)$ & $15(6)$ & $12(5)$ & 0.58 \\
\hline No $\mathrm{IMI}^{4}$ & $80(35)$ & $85(34)$ & $88(37)$ & 0.58 \\
\hline
\end{tabular}

${ }^{\mathrm{a}, \mathrm{b}}$ Values with the same superscript within a row are not different $(P>0.05)$.

${ }^{1} \mathrm{~A}$ chronic IMI was defined as SCC $\geq 200,000$ cells $/ \mathrm{mL}$ before and after the DP.

${ }^{2} \mathrm{~A}$ cured IMI was defined as SCC $\geq 200,000$ cells $/ \mathrm{mL}$ before and $\mathrm{SCC}<200,000$ cells $/ \mathrm{mL}$ after the DP.

${ }^{3} \mathrm{~A}$ new IMI was defined as SCC $<200,000$ cells $/ \mathrm{mL}$ before and SCC $\geq 200,000$ cells/mL after the DP.

${ }^{4}$ No IMI was defined as SCC $<200,000$ cells $/ \mathrm{mL}$ before and after the DP.

postpartum SCC in cows with a $0-\mathrm{d}$ DP in the current study is in contrast with earlier studies of Gulay et al. (2003) and Rastani et al. (2005), but it is in line with Pezeshki et al. (2007) and Steeneveld et al. (2013). The greater postpartum SCC in cows with a 0 -d DP may be the consequence of uncured IMI before calving because of the lack of both a DP and treatment with dry cow antibiotics. Cows with a 0 -d DP, however, have lower milk production in the subsequent lactation, resulting in a lower dilution effect, which may also explain the increased SCC (Steeneveld et al., 2013). Additionally, the udder involutes in cows with a DP compared with cows with a 0-d DP. Udders that are fully involuted are highly resistant to new IMI (Oliver and Sordillo, 1989), probably through the increase of immunoglobulins and lactoferrin in lacteal secretions during the DP (Hurley and Rejman, 1993). Cows with a 0-d DP or 30-d DP do not have a fully involuted udder during the precalving period and may have a lower concentration of lactoferrin and immunoglobulins in milk. Moreover, milking twice daily instead of once daily in the week before drying off decreased the concentration of lactoferrin in milk (Newman et al., 2009). Cows with a 30-d DP, but especially cows with a 0-d DP, may therefore be more prone to a greater SCC in the subsequent lactation.

It is unknown if the observed high SCC in early lactation in cows with a $0-d$ DP is actually correlated with intramammary bacterial infections. If the greater postpartum SCC in cows with a 0-d DP is indeed related to bacterial infections, then a $0-\mathrm{d}$ DP would not be an attractive alternative to using dry cow antibiotics to prevent IMI during the precalving period. New IMI during the precalving period in cows with a $0-d$ DP could also be the result of withholding preventive dry cow antibiotics in these cows compared with cows with a $30-\mathrm{d}$ or $60-\mathrm{d}$ DP. The significance of DP length in 4 interactions in the final model for predicting postpartum SCC could thus be explained by either DP length, use of preventive dry cow antibiotics, or both.

In many countries, blanket dry cow treatment with antibiotics is advised, and application of a DP is therefore confounded with the administration of preventive dry cow antibiotics as is omitting the DP altogether without administering preventive dry cow antibiotics. We excluded cows with a SCC $>250,000$ on the last test-day before the conventional drying-off day, based on the currently used attention levels for high SCC in multiparous cows in the Netherlands (Scherpenzeel et al., 2014). Our results suggest that cows with a SCC $>200,000$ cells $/ \mathrm{mL}$ on the last test-day should also be treated with antibiotics and have a DP matching with the withdrawal time. In the subsequent lactation, cows with a 30-d DP had a lower SCC than cows with a 0-d DP. In contrast, cows with a $30-d$ DP had a greater SCC than cows with a $60-d$ DP in the subsequent lactation. In the current study, a 30-d and 60-d DP was confounded by the use of preventive dry cow antibiotics. To our knowledge, the effect of a 30-d DP without preventive dry cow antibiotics on postpartum SCC has not yet been evaluated.

Prevalence of cows with $\mathrm{SCC} \geq 200,000$ cells $/ \mathrm{mL}$ at the first test-day postpartum tended to be greater in cows with a $0-d$ DP. Cows with a $0-d$ DP had a greater occurrence of chronic IMI than cows with a 30-d or 60-d DP. This finding suggests that a $0-d$ DP is not beneficial for cows with an IMI on the last test-day 
Table 4. Final multivariable model for prediction of postpartum average SCC between wk 2 and 44 in lactation for cows with a 0-, 30-, or 60-d dry period $[\mathrm{LSM} \pm \mathrm{SEM} \text { or regression coefficient }(\beta) \text { with SE }]^{1}$

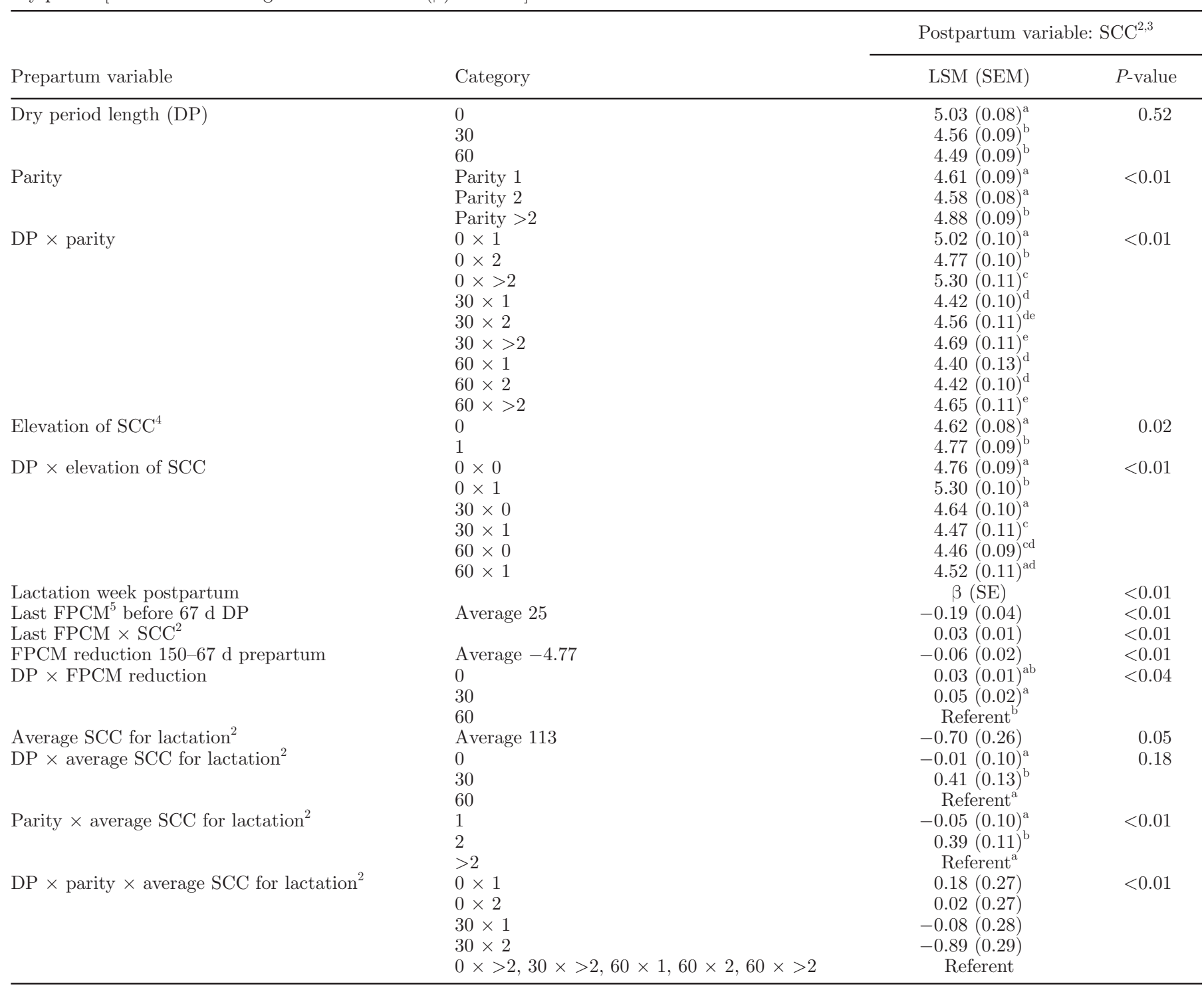

${ }^{\mathrm{a}-}$ Values with the same superscript per variable are not different $(P>0.05)$.

${ }^{1}$ The final multivariable model was based on 11 univariable models, with individual prepartum variables as independent variables, to identify potential predictors for postpartum average SCC.

${ }^{2} \mathrm{SCC}$ is shown as the natural logarithm of SCC (lnSCC).

${ }^{3} \mathrm{SCC}$ was monitored between 2 and 44 wk in lactation.

${ }^{4}$ An elevation of SCC in milk was defined as SCC in milk $\geq 200,000$ cells $/ \mathrm{mL}$ after 2 previous weeks with SCC $<200,000$ cells $/ \mathrm{mL}$.

${ }^{5} \mathrm{FPCM}=$ fat- and protein-corrected milk.

before the conventional drying-off day. An IMI before the conventional drying-off day has a better chance of being cured during a DP treatment with dry cow antibiotics. The greater proportion of chronic IMI in cows with a 0-d DP was related with a lower cure rate of IMI. Compared with previous studies using a 30-d or 60-d DP (Church et al., 2008) or a 60-d DP (Pantoja et al., 2009a), the proportion of cows with a chronic IMI was lower and the proportion of cows with a cured IMI in cows with a $30-d$ or 60-d DP was greater in the current study. The proportion of cows with a new IMI was either greater (Church et al., 2008) or smaller (Pantoja et al., 2009a) and the proportion of cows with no high SCC was smaller (Church et al., 2008) or not 
different (Pantoja et al., 2009a) in cows with a 30-d or $60-d$ DP in this study. These differences in the effect of DP length among different studies, may not only be explained by the effect of DP length itself, but also by management factors, such as experimental set-up and herd management, or by different definitions for IMI among studies.

Factors relevant for udder health in the subsequent lactation include interactions of DP length with udder health variables, parity, and milk production. To identify cow characteristics that can be used by farmers to optimize DP length for individual cows, prepartum variables were selected that can be calculated on every farm with milk production recording. The prepartum variable of having at least 1 elevation of SCC was based on monthly test-day SCC. Results of the current study indicate that postpartum SCC is affected by having at least 1 elevation of SCC in the previous lactation. The prepartum variable FPCM reduction between 150 and $67 \mathrm{~d}$ prepartum, as a measure for persistency, was negatively correlated with postpartum SCC. Less persistent cows had higher SCC postpartum, which could be explained by the higher prevalence of IMI (SCC $\geq 200,000$ cells $/ \mathrm{mL}$ ) on the last test-day before the conventional drying-off day. Milk production at drying off as such was not included in the model because it was not comparable among groups with different DP lengths in our study. The interaction of DP length with prepartum FPCM reduction revealed that a 60-d DP was beneficial for postpartum SCC. In cows with a FPCM reduction of $>5 \mathrm{~kg}$ between 150 and $67 \mathrm{~d}$ prepartum, postpartum SCC was lowest when they had a 60-d DP compared with a 0-d or 30-d DP. Additionally, it is practical to dry off a cow with a large reduction of FPCM before the conventional drying-off day at 60-d prepartum. From the 3-way interaction of DP length with parity and prepartum average SCC for lactation, the effect of DP length on postpartum average SCC appears to depend on parity and prepartum SCC. The identified characteristics can be used in a decision support model to optimize DP length for individual cows, which may support the farmer in the optimal DP strategy for individual cows.

Other management measures to reduce the risk of new IMI during the precalving period include cow-level measures, such as dry cow antibiotics and internal teat sealants, and herd-level measures, such as housing, hygiene, and to a certain extent feeding (Green et al., 2008). Preventive use of dry cow antibiotics has long been an important management measure to prevent new IMI during the precalving period, but it is no longer allowed in several European countries, including the Netherlands (Scherpenzeel et al., 2014). Other management factors to prevent new IMI during the precalving period, such as shortening or omitting the DP, have become more important. Simultaneously, management measures such as environmental factors that influence udder health also require attention. Environmental factors such as experimental set-up, housing (tie-stall vs. freestall, bedding, and grazing) and herd management factors (i.e., hygiene measures, protocols, and personnel) differ among herds and experiments, and they contribute to variation among herds and experiments (Green et al., 2008). Therefore, including knowledge of management measures on herd level is important in the DP approach for individual cows. Management factors

Table 5. Final multivariable models for prediction of postpartum at least one elevation of SCC between wk 3 and 44 in lactation and clinical mastitis between wk 1 and 44 in lactation after a 0-, 30-, or 60-d dry period [values represent occurrence, odds ratio (OR) with confidence interval, and $P$-value]

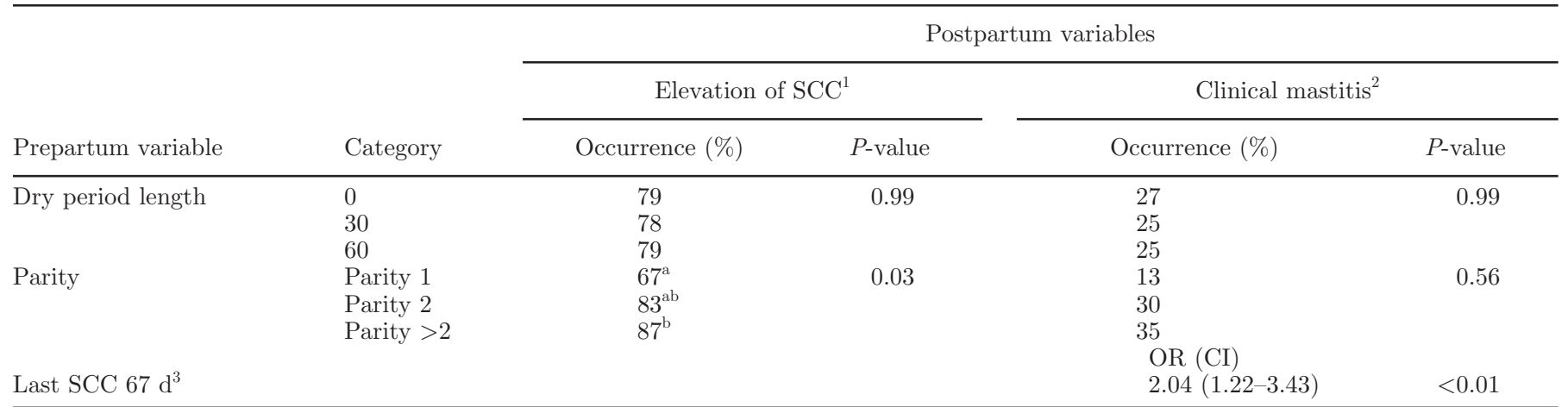

${ }^{\mathrm{a}-\mathrm{c}}$ Values with the same superscript per variable are not different $(P>0.05)$.

${ }^{1}$ Elevation of SCC was evaluated between 3 and 44 wk in lactation. An elevation of SCC in milk was defined as at least one elevation of SCC $\geq 200,000$ cells $/ \mathrm{mL}$ after 2 previous weeks with SCC $<200,000$ cells $/ \mathrm{mL}$.

${ }^{2}$ Clinical mastitis was evaluated between wk 1 and 44 in lactation.

${ }^{3} \mathrm{SCC}$ is shown as the natural logarithm of SCC (lnSCC). 
should thus be included in a decision support model to optimize DP strategies for individual cows, but they could not be determined from our study because it was performed in only 1 herd.

The number of cows with at least 1 elevation of SCC or with at least 1 case of clinical mastitis postpartum did not differ among DP lengths, despite the greater postpartum average SCC for lactation in cows with a 0-d DP. To our knowledge, studies that report the effect of omitting the DP on mastitis incidence are limited (Rastani et al., 2005; Schlamberger et al., 2010), and studies that report the effect of DP length on SCC elevation in the subsequent lactation are absent. Across studies, drawing definite conclusions on the consequences of shortening (Pezeshki et al., 2007; Watters et al., 2008; Santschi et al., 2011) or omitting (Rastani et al., 2005) the DP for mastitis is difficult. In several studies, including the current study, animal numbers are limited. Moreover, lack of clear or consistent effects is possibly also due to variation among studies with respect to definition of mastitis and disease status at the start of the experiment.

In our study, a greater last SCC before the conventional drying-off day was associated with a 2 times greater risk of at least 1 case of clinical mastitis in the subsequent lactation. In previous studies, high SCC $(\geq 200,000$ cells $/ \mathrm{mL})$ was associated with a 2 times greater risk of clinical mastitis in the same lactation (van den Borne et al., 2011) and a 4.2 times greater risk of clinical mastitis in next lactation (Pantoja et al., 2009b). The low odds for at least 1 case of clinical mastitis or at least 1 elevation of SCC postpartum, compared with Pantoja et al. (2009b), is probably because of the low prepartum occurrence of clinical mastitis and elevations of SCC in our study. Pantoja et al. (2009b) reported a $25 \%$ occurrence of clinical mastitis in previous lactation with 1.4 cases per cow, and the current study reports a $20 \%$ occurrence of clinical mastitis in previous lactation, with 1.16 cases/cow. Selection for low SCC at 2 test-days prepartum resulted in a low last SCC before the conventional drying-off day. Cows with a SCC $\geq 250,000$ cells $/ \mathrm{mL}$ at 2 test-days before the conventional drying-off day likely had an IMI and were therefore not included in our study. These cows should be treated with dry cow antibiotics to cure IMI. From this study, a 60-d DP also appears to be beneficial in cows with SCC $>200,000$ on the last test-day before the conventional drying-off day. On the one hand, a 30-d DP could be beneficial in cows with a low reduction or increase of FPCM between 150 and $67 \mathrm{~d}$ prepartum. On the other hand, a 0-d DP could be beneficial in cows with a low reduction or increase of FPCM between 150 and $67 \mathrm{~d}$ prepartum, without an elevation of SCC in previous lactation.

\section{CONCLUSIONS}

A 0-d DP resulted in a greater SCC in the subsequent lactation compared with a 30-d or 60-d DP. A 30-d or 0-d DP did not affect the occurrence of at least 1 elevation of $\mathrm{SCC} \geq 200,000$ cells $/ \mathrm{mL}$ or the occurrence of clinical mastitis postpartum compared with a $60-\mathrm{d}$ DP. A 0-d DP is disadvantageous in cows with a SCC $\geq 200,000$ cells $/ \mathrm{mL}$ on the last test-day before the conventional drying-off day because these cows were found to have a greater occurrence of chronic IMI and a lower cure rate during the precalving period than cows with a 30-d or 60-d DP. Cow characteristics other than DP length that predict postpartum udder health are parity, prepartum elevations of SCC, average prepartum SCC for lactation, FPCM reduction between 150 and $67 \mathrm{~d}$ prepartum, and last FPCM and last SCC before the conventional drying-off day.

\section{ACKNOWLEDGMENTS}

The authors thank the Dutch Dairy Board (PZ, The Netherlands), the Product Board Animal Feed (PDV, the Netherlands), and CRV (the Netherlands) for financing the original experiment. The current study was part of the Public-Private Partnership 'Sustainable Dairy Chain' (Duurzame Zuivelketen, the Netherlands), and was financed by DairyNL (Zuivel NL; organization of the Dutch dairy supply chain, the Netherlands) and the Dutch Ministry of Economic Affairs (EZ, the Netherlands).

\section{REFERENCES}

Bernier-Dodier, P., L. Delbecchi, G. F. Wagner, B. G. Talbot, and P. Lacasse. 2010. Effect of milking frequency on lactation persistency and mammary gland remodeling in mid-lactation cows. J. Dairy Sci. 93:555-564.

Capuco, A. V., R. M. Akers, and J. J. Smith. 1997. Mammary growth in Holstein cows during the dry period: Quantification of nucleic acids and histology. J. Dairy Sci. 80:477-487.

Chen, J., J. J. Gross, H. A. van Dorland, G. J. Remmelink, R. M. Bruckmaier, B. Kemp, and A. T. M. van Knegsel. 2015. Effects of dry period length and dietary energy source on metabolic status and hepatic gene expression of dairy cows in early lactation. J. Dairy Sci. 98:1033-1045.

Church, G. T., L. K. Fox, C. T. Gaskins, D. D. Hancock, and J. M. Gay. 2008. The effect of a shortened dry period on intramammary infections during the subsequent lactation. J. Dairy Sci. 91:4219-4225.

Collier, R. J., E. L. Annen-Dawson, and A. Pezeshki. 2012. Effects of continuous lactation and short dry periods on mammary function and animal health. Animal 6:403-414.

Green, M. J., A. J. Bradley, G. F. Medley, and W. J. Browne. 2007. Cow, farm, and management factors during the dry period that determine the rate of clinical mastitis after calving. J. Dairy Sci. 90:3764-3776.

Green, M. J., A. J. Bradley, G. F. Medley, and W. J. Browne. 2008. Cow, farm, and herd management factors in the dry period associated with raised somatic cell counts in early lactation. J. Dairy Sci. 91:1403-1415. 
Grummer, R. R., and R. R. Rastani. 2004. Why reevaluate dry period length? J. Dairy Sci. 87:E77-E85.

Gulay, M. S., M. J. Hayen, K. C. Bachman, T. Belloso, M. Liboni, and H. H. Head. 2003. Milk production and feed intake of Holstein cows given short (30-d) or normal (60-d) dry periods. J. Dairy Sci. 86:2030-2038.

Hurley, W. L., and J. J. Rejman. 1993. Bovine lactoferrin in involuting mammary tissue. Cell Biol. Int. 17:283-289.

Kuhn, M. T., J. L. Hutchison, and H. D. Norman. 2006. Effects of length of dry period on yields of milk fat and protein, fertility and milk somatic cell score in the subsequent lactation of dairy cows. J. Dairy Res. 73:154-162.

Newman, K. A., P. J. Rajala-Schultz, J. Lakritz, and F. J. DeGraves. 2009. Lactoferrin concentrations in bovine milk prior to dry-off. J. Dairy Res. 76:426-432.

Oliver, S. P., and L. M. Sordillo. 1989. Approaches to the manipulation of mammary involution. J. Dairy Sci. 72:1647-1664.

Pantoja, J. C. F., C. Hulland, and P. L. Ruegg. 2009a. Dynamics of somatic cell counts and intramammary infections across the dry period. Prev. Vet. Med. 90:43-54.

Pantoja, J. C. F., C. Hulland, and P. L. Ruegg. 2009b. Somatic cell count status across the dry period as a risk factor for the development of clinical mastitis in the subsequent lactation. J. Dairy Sci. 92:139-148.

Pezeshki, A., J. Mehrzad, G. R. Ghorbani, H. R. Rahmani, R. J. Collier, and C. Burvenich. 2007. Effects of short dry periods on performance and metabolic status in Holstein dairy cows. J. Dairy Sci. 90:5531-5541.

Pinedo, P., C. Risco, and P. Melendez. 2011. A retrospective study on the association between different lengths of the dry period and subclinical mastitis, milk yield, reproductive performance, and culling in Chilean dairy cows. J. Dairy Sci. 94:106-115.

Rastani, R. R., R. R. Grummer, S. J. Bertics, A. Gümen, M. C. Wiltbank, D. G. Mashek, and M. C. Schwab. 2005. Reducing dry period length to simplify feeding transition cows: Milk production, energy balance, and metabolic profiles. J. Dairy Sci. 88:1004-1014.

Santschi, D. E., D. M. Lefebvre, R. I. Cue, C. L. Girard, and D. Pellerin. 2011. Incidence of metabolic disorders and reproductive performance following a short (35-d) or conventional (60-d) dry period management in commercial Holstein herds. J. Dairy Sci. 94:3322-3330.
SAS Institute Inc. 2011. The SAS System for Windows. Release 9.3. SAS Institute Inc., Cary, NC.

Scherpenzeel, C. G., I. E. den Uijl, G. van Schaik, R. G. Olde Riekerink, J. M. Keurentjes, and T. J. G. M. Lam. 2014. Evaluation of the use of dry cow antibiotics in low somatic cell count cows. J. Dairy Sci. 97:3606-3614.

Schlamberger, G., S. Wiedemann, E. Viturro, H. H. D. Meyer, and M. Kaske. 2010. Effects of continuous milking during the dry period or once daily milking in the first 4 weeks of lactation on metabolism and productivity of dairy cows. J. Dairy Sci. 93:2471-2485.

Schukken, Y. H., D. J. Wilson, F. Welcome, L. Garrison-Tikofsky, and R. N. Gonzalez. 2003. Monitoring udder health and milk quality using somatic cell counts. Vet. Res. 34:579-596.

Shoshani, E., S. Rozen, and J. J. Doekes. 2014. Effect of a short dry period on milk yield and content, colostrum quality, fertility, and metabolic status of Holstein cows. J. Dairy Sci. 97:2909-2922.

Steeneveld, W., Y. H. Schukken, A. T. M. van Knegsel, and H. Hogeveen. 2013. Effect of different dry period lengths on milk production and somatic cell count in subsequent lactations in commercial Dutch dairy herds. J. Dairy Sci. 96:2988-3001.

Steeneveld, W., A. T. M. van Knegsel, G. J. Remmelink, B. Kemp, J. C. M. Vernooij, and H. Hogeveen. 2014. Cow characteristics and their association with production performance with different dry period lengths. J. Dairy Sci. 97:4922-4931.

van den Borne, B. H. P., J. C. M. Vernooij, A. M. Lupindu, G. van Schaik, K. Frankena, T. J. G. M. Lam, and M. Nielen. 2011. Relationship between somatic cell count status and subsequent clinical mastitis in Dutch dairy cows. Prev. Vet. Med. 102:265-273.

van Knegsel, A. T. M., G. J. Remmelink, S. Jorjong, V. Fievez, and B. Kemp. 2014. Effect of dry period length and dietary energy source on energy balance, milk yield, and milk composition of dairy cows. J. Dairy Sci. 97:1499-1512.

van Knegsel, A. T. M., S. G. A. van der Drift, J. Čermáková, and B. Kemp. 2013. Effects of shortening the dry period of dairy cows on milk production, energy balance, health, and fertility: A systematic review. Vet. J. 198:707-713.

Watters, R. D., J. N. Guenther, A. E. Brickner, R. R. Rastani, P. M. Crump, P. W. Clark, and R. R. Grummer. 2008. Effects of dry period length on milk production and health of dairy cattle. J. Dairy Sci. 91:2595-2603 